\title{
EFEKTIVITAS PELAKSANAAN LELANG JABATAN
}

\section{Fitri Wahyuni Nengsih}

Jurusan Administrasi Publik, Fakultas Ilmu Sosial, Universitas Negeri Padang

Email: wahyuninengsihfitri@gmail.com

\section{Syamsir}

Jurusan Administrasi Publik, Fakultas Ilmu Sosial, Universitas Negeri Padang Email: syamsir@unp.ac.id

\begin{abstract}
This study discussed the effectiveness of auctioning positions in the Padang City Government the constraints and solutions faced in the auction. The effectiveness of the auctioning was seen based on the Minister of Administrative Reform and Bureaucratic Reform Regulation No.13 of 2014 concerning the Procedure for Filling in High Level Leadership Positions in Government Agencies. The research method used was descriptive qualitative. Data were obtained by observation, interview and documentation study. Informants was determined by purposive sampling technique. The results of this study showed that the auction office in Padang City has not been effectively based on PERMENPAN-RB No.13 of 2014 because there were four tests that were not carried out in accordance with the regulation. The constraints faced in the implementation of this auction are the minimum budget for the implementation of auction positions and the existence of new regulations from the central government which are quite burdensome in the implementation of auction positions and the background of the selection committee's scientific background which was less relevant to the auctioned position. The solution was optimize the use of the existing budget and change or change the selection method according to budget capabilities.
\end{abstract}

Keywords: Effective, job auction, constraints and solutions

Submitted: 8 December 2018

Reviewed:30 Januari 2019

Published: 3I October 2019

How to Cite: Fitri Wahyuni Nengsih dan Syamsir. 2019. Feminisme Efektivitas Pelaksanaan Lelang Jabatan. 3(2): pp. 124-134. DOI:https://doi.org/10.24036/jess/vol3-iss2

\section{Pendahuluan}

Reformasi birokrasi merupakan upaya pemerintah dalam mewujudkan good governance. Melalui reformasi birokrasi, dilakukan penataan terhadap sistem penyelenggaraan pemerintah agar lebih efektif dan efisien. Salah satu wujud dari penerapan reformasi birokrasi ini adalah dengan dilaksanakannya pengisian jabatan pimpinan tinggi secara terbuka atau lebih dikenal dengan lelang jabatan. Pengisian jabatan pimpinan tinggi secara terbuka telah diatur dalam UU No. 5 Tahun 2014 tentang ASN untuk itu Kementrian Pendayagunaan dan Aparatur Negara dan Reformasi Birokrasi mengeluarkan PERMENPAN-RB No. 13 Tahun 2014 tentang tata cara pengisian jabatan pimpinan tinggi secara terbuka di lingkungan instansi pemerintah.

Keluarnya PERMENPAN-RB No. 13 tahun 2014 mengisyaratkan kepada setiap pemerintah baik pusat maupun daerah untuk melakukan lelang jabatan 
dalam pengisian jabatan pimpinan tinggi. Salah satunya Pemerintahan Kota Padang, Pemerintah Kota Padang telah melakukan lelang jabatan pada tahun 2015 yaitu untuk jabatan Kepala Dinas Pariwisata dan Kebudayaan, Dinas Kelautan dan Perikanan, Dinas Pekerjaan Umum, Satuan Polisi Pamong Praja (Satpol PP), Badan Pengelola Keuangan dan Aset (BPKA), dan Dinas Pendapatan Daerah (Dispenda) dan Dinas Pasar Kota Padang. Pada tahun 2016 lelang jabatan dilakukan untuk memilih Sekretaris Daerah Kota Padang, Dinas Kesehatan Kota Padang, Dinas Kebersihan dan Pertamanan Kota Padang, dan Dinas Sosial dan Tenaga Kerja Kota Padang. Pada tahun 2017 pemerintah Kota Padang juga telah melakukan lelang jabatan untuk Dinas Pendidkan, Dinas Pemuda dan Olah Raga, Dinas Pertanian Kota Padang dan Dinas Perumahan Rakyat, Kawasan Permukiman dan Pertanahan Kota Padang. (www.bkd.padang.go.id, diakses 8 Maret 2017)

Dalam pelaksanaan lelang jabatan di Kota Padang ditemui adanya unsur intervensi dari pemerintah Kota Padang seperti pelaksanaan lelang jabatan untuk Sekretaris Daerah dimana salah satu syaratnya harus memiliki izin dari Walikota Padang untuk ASN yang berada di lingkungan pemerintahan Kota Padang. Sedangkan dalam PERMENPAN-RB No.13 Tahun 2014 dapat dilihat bahwa tidak ada disebutkan persyaratan harus mendapatkan izin dari Pimpinan khususnya Pejabat Pembina Kepegawaian jika ingin berpartisipasi dalam lelang jabatan. Dalam PERMENPAN-RB dijelaskan untuk melindungi Pegawai ASN dari pengaruh-pengaruh politis yang tidak pantas/tepat serta memberikan perlindungan dari hukum yang tidak adil dan tidak terbuka.

Selanjutnya Panitia Seleksi yang dipilih oleh Walikota dan Sekretaris Daerah Kota Padang kebanyakan tidak memiliki latar belakang keilmuwan yang sesuai dengan jabatan yang dilelang, sehingga pada saat wawancara dan penyampaian pokok-pokok pikiran, apa yang disampaikan pelamar kepada Panitia Seleksi mereka kurang memahami maksud yang disampaikan oleh pelamar karena Panitia Seleksi tidak memiliki keilmuwan di bidang tersebut. Lelang jabatan yang diharapkan dapat menghasilkan pejabat yang berkompeten namun dalam kenyataannya masih saja ditemui bahwa kepala dinas yang terpilih dalam lelang jabatan tidak melaksanakan tugasnya dengan baik seperti Kepala Dinas Pekerjaan Umum Kota Padang Fatriarman Noer. Fatriarman Noer sering tidak berada dikantor sehingga sulit untuk berurusan dan Fatriarman Noer juga dianggap gagal dalam mengelola keuangan dan menyebabkan dana APBD tidak terkelola sesuai dengan perencanaan.

Berdasarkan masalah tersebut maka persoalan yang ingin dikaji dalam penelitian ini antara lain: 1) Kendala dihadapi dalam pelaksanaan lelang jabatan di lingkungan Pemerintahan Kota Padang 2) Efektivitas pelaksanaan lelang jabatan di lingkungan Pemerintahan Kota Padang 3) Solusi untuk meminimalisasi kendala-kendala dalam pelaksanaan lelang jabatan di lingkungan Pemerintahan Kota Padang.

\section{Tinjauan Kepustakaan}

\section{Konsep Efektivitas}

Efektivitas berasal dari kata dasar efektif dalam bahasa Inggris effective yang artinya berhasil atau sesuatu yag dilakukan berhasil dengan baik. The Liang Gie 
dalam Abdul Halim (2004) mengungkapkan efektivitas merupakan keadaan yang terjadi sebagai akibat yang dikehendaki. Hal ini berarti suatu perbuatan yang dilakukan seseorang dengan adanya maksud atau tujuan tertentu, maka perbuatan itu dikatakan efektif jika menimbulkan akibat atau mencapai tujuan yang ditentukan sebelumnya.

Menurut Gibson dalam buku Manajemen Perkantoran; Efektif, Efisien dan Profesional (2013) "Efektivitas adalah konteks prilaku organisasi yang merupakan hubungan antara produksi, kualitas, efisiensi, fleksibilitas, kepuasan, sifat keunggulan dan pengembangan." Dari pengertian tersebut dapat disimpulkan bahwa efektivitas adalah melihat secara keseluruhan dari organisasi atau kegiatan, tidak hanya mempertimbangkan prosesnya saja tapi juga hasil dari proses tersebut serta faktor-faktor lain yang berhubungan dengan proses tersebut seperti fleksibilitas, kepuasan, sifat keunggualan dan pengembangan.

Untuk mengukur efektif atau tidaknya pelaksanaan lelang jabatan maka digunakan indikator efektivitas Gibson. Gibson dalam Tangkilisan (2005) menyebutkan 7 (tujuh) indikator efektivitas yaitu (1) kejelasan tujuan yang hendak dicapai: Sondang P. Siagian (2001) menyebutkan tujuan digunakan untuk pedoman dalam melaksanakan suatu program atau kegiatan. (2) Kejelasan strategi pencapaian tujuan: Untuk bisa mencapai tujuan yang di inginkan diperlukan strategi-strategi atau cara-cara yang digunakan untuk mencapai tujuan tersebut. (3) Proses analisis dan perumusan kebijaksanaan yang mantap yaitu kebijakan yang di ambil harus dapat mendukung dalam proses pencapaian tujuan dengan stragtegi/cara yang telah ditentukan. (4) Perencanaan yang matang: Sondang P. Siagian (2001) menyatakan perencanaan sebagai suatu proses untuk menetapakan sekarang apa yang akan dikerjakan pada waktu yang akan datang. (5) Penyusunan program yang tepat: Melayu S.P Hasibuan (2011) menyatakan program yaitu sebuah rencana yang telah tergambar dengan jelas sasaran, prosedur maupun anggarannya. (6) Tersedianya sarana dan prasarana: Sarana dan prasarana adalah suatu komponen untuk mendukung tercapainya tujuan. (7) Sistem pengawasan dan pengendalian yang bersifat mendidik: Sondang P. Siagian (2011) menyebutkan pengawasan harus dilakukan karena manusia sebagai penyelenggara adalah makhluk yang tidak sempurna serta memiliki keterbatasan dalam mengartikan sesuatu rencana.

\section{Lelang Jabatan Berdasarkan PERMENPAN-RB No.13 Tahun 2014}

Lelang jabatan atau promosi jabatan secara terbuka merupakan sebuah cara yang digunakan dalam melakukan pengangkatan dan penempatan ASN dalam jabatan struktural atau jabatan yang lebih tinggi melalui seleksi yang sifatnya terbuka. Dalam PERMENPAN-RB No.13 Tahun 2014 disebutkan 3 tahapan pelaksanaan lelang jabatan, yaitu:

a. Persiapan

Panitia seleksi dibentuk oleh Pejabat Pembina Kepegawaian dengan berkoordinasi dengan KASN yang terdiri dari pejabat dari instansi yang bersangkutan dan pejabat dari instansi lain yang terkait dengan jabatan yang lowong serta pakar atau akademisi ataupun profesional. Pemilihan dengan 
memperhatikan pengetahuan dan pengalaman yang relevan dengan jabatan yang lowong.

b. Pelaksanaan

Pelaksanaan lelang jabatan berdasarkan PERMENPAN-RB No. 13 Tahun 2014, yaitu:

a) Pengumuman dilakukan secara terbuka lewat media cetak, online, papan pengumuman maupun surat edaran. Waktu pengumuman paling sedikit 15 hari kerja. Dalam pengumuman tersebut harus berisi tentang jabatan yang lowong, syarat administrasi yang dibutuhkan, jadwal, sistem seleksi dan tahapan pelaksanaan.

b) Seleksi administrasi dilakukan oleh sekretariat panitia seleksi, dalam satu jabatan yang lowong calon pejabat yang lulus seleksi administrasi minimal 3 orang. Seleksi administrasi didasarkan pada kualifikasi, kompetensi kepangkatan, pendidikan, rekam jejak jabatan yang sesuai dengan jabatan yang lowong.

c) Seleksi kompetensi dibagi menjadi seleksi kompetensi manajerial dan kompetensi bidang. Kompetensi manajerial dapat dilakukan dengan psikometri, wawancara kompetensi, analisis kasus/presentasi. Sedangkan kompetensi bidang dapat dilakukan dengan tes tertulis, wawancara dan lainnya.

d) Wawancara akhir dilaksanakan oleh Panitia Seleksi yang bersifar memperdalam pelamar dari hal motivasi, minat, prilaku serta karakter. Saat wawancara bisa mengikutsertakan pengguna dari jabatan yang akan diisi.

e) Penelusuran (rekam jejak) dilaksanakan dengan melihat rekam jejak jabatan serta pengalaman dengan tujuan melihat relevansi terhadap jabatan yang akan diisi. Jika terdapat kejanggalan maka dilakukan klarifikasi dengan instansi yang bersangkutan. Penelusuran ke tempat bekerja baik kepada atasan, bawahan maupun rekan sejawat serta dengan lingkungan lainnya.

f) Hasil seleksi diumumkan kepada setiap peserta. Panitia Seleksi mengolah hasil dari setiap tahapan seleksi dan menyusun peringkat nilai, sehingga muncullah nama tiga besar. Peringkat nilai ini disampaikan kepada Pejabat Pembina Kepegawaian yang peringkat nilainya bersifat rahasia. Selanjutnya hasil tersebut di umumkan dan disampaikan kepada pejabat berwenang dan Pejabat berwenanglah yang menyampaikan tiga nama ini kepada Walikota selaku Pejabat Pembina Kepegawaian.

g) Tes kesehatan dan psikologi dapat dilaksanakan dengan bekerjasama dengan unit pelayanan kesehatan pemerintah serta lembaga psikologi.

c. Monitoring dan evaluasi

Monitoring dan evaluasi dilakukan oleh Komisi Aparatur Sipil Negara dengan melaporkan secara tertulis kepada KASN sebelum dan sesudah kegiatan lelang jabatan dilaksanakan. 


\section{Kendala dan Solusi dalam Lelang Jabatan/Rekrutmen}

Simamora sebagaimana yang dikutip oleh Suwanto dan Donni Juni Priansa (2014) menjelaskan beberapa kendala yang ditemui dalam rekrutmen meliputi:

a. Karakteristik Organisasional: Karakteristik organisasional mempengaruhi desain dan implementasi sistem rekrutmen.

b. Citra Organisasi: Citra organisasi yang dianggap rendah akan mengurangi minat pelamar untuk melamar bekerja pada organisasi tersebut.

c. Kebijakan Organisasional: Informasi analisis pekerjaan dan perencanaan kepegawaian mengarahkan perekrutan dalam mengambil keputusan mengenai sumber dan saluran rekrutmen yang tepat dan mengevaluasi proses rekruitmen..

d. Rencana strategik dan rencana sumber daya manusia

e. Kebiasaan perekrut

f. Kondisi eksternal: Kondisi pasar tenaga kerja merupakan faktor utama dalam lingkungan eksternal yang mempengaruhi penarikan. Peraturanperaturan dari pemerintah dan serikat pekerja yang ikutberpengaruh terhadap rekrutmen.

g. Daya tarik pekerjaan

h. Persyaratan pekerjaan

Elfin Defriadi (2016) dalam skripsinya Rekrutmen Pejabat Struktural Melalui Model Lelang Jabatan Di Pemerintahan Provinsi Daerah Istimewa Yogyakarta juga mengungkapkan ada beberapa kendala dalam lelang jabatan, yaitu sebagai berikut: 1) Waktu; 2) Anggaran pembiayaan pelaksanaan lelang jabatan menguras biaya cukup mahal karena proses seleksi lelang jabatan tersebut memakan waktu proses yang cukup panjang serta melibatkan pihak-pihak berkepentingan dan biaya-biaya penunjang di dalamnya sehingga anggaran yang diperlukan dibebankan dari APBD; 3) Prilaku budaya birokrasi: prilaku budaya birokrasi di DI Yogyakarta yaitu mempunyai rasa tidak enakan (pekiwuhn). 4) Mental block: pegawai yang mengikuti lelang jabatan untuk pertama kali memberikan pengaruh yang signifikan terhadap sikap dan mental para pegawai yang mengikuti seleksi.

Solusi untuk mengurangi kendala dalam pelaksanaan lelang jabatan yang ditawarkan oleh Made Gede Budhiarta (2005) dalam tesisnya Pengembangan Mode Pola Karir Pejabat Struktural melalui Job Tender di Sekretariat Daerah Kabupaten Jembrana yaitu: (1) Dengan meningkatkan kualitas sumber daya aparatur melalui Diklat; (2) Biaya pelaksanaan lelang jabatan yang cukup mahal, pemerintah memerlukan suatu strategi pengaturan anggaran sehingga dapat mencukupi untuk pembiayaan proses pelaksanaan lelang jabatan; (3) Kondisi birokrasi yang masih malu-malu atau segan kepada atasan untuk ikut serta dalam lelang jabatan harus dipacu, diberikan motivasi-motivasi dan pengetahuan yang lebih tentang lelang jabatan tersebut sehingga dapat merubah mindset aparatur. 


\section{Metode Penelitian}

Jenis penelitian ini adalah penelitian kualitatif. Penelitian dilakukan pada beberapa instansi di Kota Padang. Informan dipilih dengan metode purposive yaitu memilih informan berdasarkan pertimbangan tertentu yang dianggap dapat memberikan informasi yang diperlukan dengan maksimal. Informan dalam penelitian ini adalah pihak-pihak yang dianggap memiliki informasi yang peneliti butuhkan.

Data primer pada penelitian ini didapatkan dengan observasi dan wawancara sedangkan data sekunder melalui dokumen-dokumen. Uji keabsahan data dilakukan dengan teknik triangulasi sumber yang digunakan untuk melihat kecocokan antara sumber yang diperoleh dari observasi, wawancara dan studi kepustakaan. Analisis data dilakukan dengan metode yang dikembangkan oleh Miles dan Huberman.

\section{Hasil Penelitian dan Pembahasan}

\section{Efektivitas Pelaksanaan Lelang Jabatan di Lingkungan Pemerintahan Kota Padang}

Dalam PERMENPAN-RB No.13 Tahun 2014 terdapat beberapa tahap dalam pelaksanaan lelang jabatan, yaitu:

a. Tahap Persiapan

Tahap persiapan dilakukan melalui Pembentukan Panitia Seleksi dengan memperhatikan pengetahuan dan pengalaman yang relevan dengan jabatan yang lowong. Namun dalam pelaksanaan lelang jabatan di Kota Padang Panitia Seleksi yang terpilih memiliki latar belakang keilmuwan yang kurang relevan dengan jabatan yang lowong seperti bidang keilmuwan teknik dan kimia. Berdasarkan keterangan dari peserta lelang jabatan bahwa pada tahap wawancara Panitia Seleksi kurang memahami maksud dari apa yang disampaikan oleh peserta mengenai jabatan yang lowong yang dilamarnya yaitu Kepala Dinas Pertanian.

b. Tahap Pelaksanaan

Tahap pelaksanaan ini terdiri dari tujuh sub tahapan yaitu pengumuman, seleksi administrasi, seleksi kompetensi, wawancara akhir, penelusuran (rekam jejak), hasil seleksi dan tes kesehatan dan psikologi. Dari 7 sub tahapan tersebut terdapat 4 sub tahapan yang tidak dilakukan dengan maksimal yaitu seleksi kompetensi. Dalam seleksi kompetensi ada dua yaitu kompetensi manajerial dan kompetensi bidang, pada tahap pelaksanaan lelang jabatan di Kota Padang seleksi kompetensi bidang tidak dilakukan. Seperti yang disampaikan oleh Kasubag Penjenjangan dan Sertifikasi BKPSDM bahwa ada dua tahap seleksi yang dilakukan yaitu kompetensi dasar dan kompetensi manajerial yang sudah disusun oleh Panitia Seleksi. Peserta lelang jabatan juga menjelaskan bahwa seleksi yang mereka ikuti yaitu kompetensi dasar dengan CAT dan kompetensi manajerial dengan FGD dan Wawancara.

Selanjutnya wawancara akhir tidak dilakukan tersendiri tapi digabungkan dengan tahap wawancara pada seleksi manajerial. Salah satu anggota Panitia 
Seleksi juga menyebutkan bahwa wawancara dilakukan oleh Panitia Seleksi dan tidak ada pihak lain dengan pertanyaan-pertanyaan yang telah disiapkan sebelumnya, tujuannya untuk mendalami karakter pelamar, pengalaman kerja sebelumnya yang pernah dijabat, visi misi mengikuti lelang jabatan, dan lainnya. Dilihat dari sifat wawancara yang dilakukan pada seleksi manajerial didalamnya juga memuat wawancara akhir. Namun dalam tahap ini tidak melibatkan orang sebagai pengguna dari jabatan yang akan diisi. Pada tahap penelusuran (rekam jejak) tidak dilakukan dengan maksimal karena rekam jejak pelamar hanya dilihat pada CV pelamar dan didalami pada saat wawancara. Serta tes kesehatan dan psikologi yang tidak dilakukan. Beberapa peserta lelang jabatan menyatakan bahwa tes kesehatan dan psikologi tidak ada dilakukan, selama proses yang diikuti hanya ada CAT, wawancara dan FGD. Kasubag Penjenjangan dan Sertifikasi BKPSDM menyatakan bahwa tes kesehatan tidak ada dilakukan namun pada syarat mendaftar harus ada surat keterangan berbadan sehat dan bersih narkoba dari rumah sakit pemerintah, hal ini dilakukan juga mengingat anggaran yang sedikit. Begitupun dengan tes psikologi tidak dilakukan dalam pelaksanaan lelang jabatan di Kota Padang.

Berdasarkan uraian di atas terlihat bahwa pelaksanaan lelang jabatan belum terlaksana dengan efektif yang diukur dengan PERMENPAN-RB No.13 Tahun 2014 tentang Tata Cara Pengisian Jabatan Pimpinan Tinggi secara Terbuka di Lingkungan Instansi Pemerintah. Dalam peraturan tersebut ada 3 tahapan dalam pelaksanaan lelang jabatan. Namun ada 2 tahapan yang tidak dilaksanakan secara maksimal dalam pelaksanaan lelang jabatan di Kota Padang yaitu tahap persiapan: pembentukan Panitia Seleksi tidak memperhatikan latar belakang keilmuwannya dan tahap pelaksanaan yang terdiri atas 7 sub tahapan, dari 7 tersebut ada 4sub tahapan yang tidak dilakukan secara optimal diantaranya tes kompetensi bidang tidak dilakukan sedangkan wawancara akhir, rekam jejak dan tes kesehatan dan psikologi tidak terlaksana dengan optimal sesuai dengan peraturan. Hal ini dikarenakan sedikitnya anggaran pelaksanaan lelang jabatan sehingga tidak memungkinkan untuk melakukan semua tes tersebut.

c. Tahap Monitoring dan Evaluasi

PERMENPAN-RB No.13 Tahun 2014 telah menyebutkan bahwa monitoring dan evaluasi dilakukan oleh Komisi Aparatur Sipil Negara dengan melaporkan secara tertulis kepada KASN sebelum dan sesudah kegiatan lelang jabatan dilaksanakan. Dalam pelaksanaan lelang jabatan di Kota Padang monitoring dan evaluasi dilakukan oleh Komisi Aparatur Sipil Negara yang berada di pusat. Pengawasan berbentuk laporan di awal dan akhir kegiatan yang disampaikan oleh Pejabat Pembina Kepegawaian yang dalam hal ini di tugaskan kepada Bagian Pengembangan Aparatur BKPSDM Kota Padang. Sebelum pelaksanaan lelang jabatan dilakukan atau diumumkan terlebih dahulu melapor dulu ke KASN, setelah keluar persetujuan dari KASN barulah lelang jabatan dapat dilakukan. Pada akhir kegiatan setelah terpilih 3 (tiga) besar maka melapor lagi ke KASN. Dari uraian tersebut dapat diketahui bahwa monitoring dan evaluasi dalam pelaksanaan lelang jabatan di Kota Padang 
sudah dilakukan dengan baik sesuai dengan PERMENPAN-RB No.13 Tahun 2014.

\section{Kendala dalam Pelaksanaan Lelang Jabatan di Lingkungan Pemerintahan Kota Padang}

Menurut Simamora dalam Suwanto dan Donni Juni Priansa (2014) menyebutkan bahwa kendala-kendala dalam proses rekruitmen yaitu kondisi eksternal yaitu adanya batasan-batasan dari pemerintah dengan adanya peraturan-peraturan yang ditetapkan oleh pemerintah. Hal yang sama juga diungkapkan oleh Melayu Hasibuan bahwa kendala dalam rekruitmen yaitu kondisi-kondisi lingkungan eksternal. Dalam pelaksanaaan lelang jabatan di Kota Padang kondisi lingkungan eksternal menjadi kendala, yaitu adanya Peraturan Pemerintah No. 63 Tahun 2016 tentang Jenis dan Tarif Atas Jenis Penerimaan Negara Bukan Pajak Yang Berlaku Pada Badan Kepegawaian Negara.

Dalam peraturan tersebut disebutkan bahwa penyelenggaraan seleksi dengan metode Computer Assisted Test (CAT) Badan Kepegawaian Negara harus membayar kepada negara sebesar Rp.100.000/peserta. Kebijakan ini mempengaruhi pelaksanaan lelang jabatan yang di lakukan di Kota Padang karena salah satu tahap seleksi lelang jabatan dilakukan dengan metode CAT dari BKN, dengan keluarnya kebijakan ini maka metode CAT tidak dapat dipakai lagi karena harus membayar kepada negara sebesar Rp.100.000/peserta. Sedangkan anggaran untuk itu belum teranggarkan sebelumnya. Berdasarkan hal tersebut dapat diketahui bahwa kebijakan tersebut menjadi kendala atau hambatan dalam pelaksanaan lelang jabatan.

Panitia Seleksi lelang jabatan yang dipilih oleh Walikota dan Sekretaris Daerah Kota Padang memiliki kompetensi keilmuwan yang kurang relevan dengan jabatan yang dilelang. Hal ini mengakibatkan apa yang disampaikan oleh Pelamar pada tahap wawancara kurang dipahami dengan baik oleh Panitia Seleksi.

\section{Solusi dalam Meminimalisir Kendala dalam Pelaksanaan Lelang Jabatan di Lingkungan Pemerintahan Kota Padang}

Kondisi lingkungan eksternal menjadi kendala dalam rekrutmen salah satunya yaitu batasan-batasan dari pemerintah dengan menerbitkan peraturanperaturan. Adanya peraturan-peraturan pemerintah menjadi batasan-batasan dalam merencanakan proses rekrutmen dan kadang juga menjadi panduan supaya sesuai dengan aturan yang berlaku. Seperti yang diungkapkan oleh Simamora (2014) bahwa kondisi eksternal menjadi salah satu kendala dalam rekrutmen. Dalam penelitian ini peraturan pemerintah yang baru keluar menjadi kendala dalam pelaksanaan lelang jabatan yang mengakibatkan tahap-tahap pelaksanaan lelang jabatan ada yang dirubah untuk menyesuaikan dengan peraturan yang ada serta kemampuan anggaran yang tersedia. Untuk itu salah satu cara yang digunakan untuk mengatasi hal tersebut dengan merubah metode seleski yang digunakan dengan metode lain yang biayanya lebih murah dan sesuai dengan anggaran yang tersedia. 
Selanjutnya Mede Gede Budhiarta (2015) dalam tesisnya Pengembangan Mode Pola Karir Pejabat Struktural melalui Job Tender di Sekretariat Daerah Kabupaten Jembrana mengungkapkan bahwa solusi untuk biaya pelaksanaan lelang jabatan yang cukup mahal, pemerintah memerlukan suatu strategi pengaturan anggaran sehingga dapat mencukupi untuk pembiayaan proses pelaksanaan lelang jabatan. Dalam hal ini BKPSDM harus mengatur sebaik mungkin anggaran yang tersedia dapat mencukupi pelaksanaan lelang jabatan sehingga dapat berjalan dengan baik. BKPSDM harus mensiasati bagaimana menggunakan anggaran yang tersedia agar kegiatan tetap terlaksana, seperti yang diungkapkan oleh Kasubag Penjenjangan dan Sertifikasi bahwa untuk mensiasati kekurangan anggaran biasanya mengurangi anggota sekretariat panitia seleksi dari 12 orang menjadi 9 orang dan mengubah metode CAT dengan ujian tertulis biasa dengan bekerjasama dengan BK UNP yang biayanya lebih murah jika dibandingkan dengan menggunakan metode CAT.

\section{Kesimpulan dan Saran}

1. Kesimpulan

Kendala dalam pelaksanaan lelang jabatan di lingkungan pemerintahan Kota Padang yaitu kondisi eksternal yang menyebutkan adanya batasan-batasan dari pemerintah dengan adanya peraturan-peraturan. Peraturan tersebut mengenai PNBP yang berlaku di BKN yaitu Peraturan Pemerintah No. 63 Tahun 2016 tentang Jenis dan Tarif Atas Jenis Penerimaan Negara Bukan Pajak Yang Berlaku Pada Badan Kepegawaian Negara. Dengan adanya peraturan baru ini mengakibatkan pelaksanaan lelang jabatan tidak dapat dilaksanakan dengan metode CAT, dikarenakan anggaran pelaksanaan lelang jabatan tidak cukup untuk membayar metode CAT serta latar belakang keilmuwan Panitia Seleksi yang kurang relevan dengan jabatan yang dilelang. Anggaran pelaksanaan yang sedikit menyebabkan tidak semua tes dapat dillaksanakan dengan optimal sesuai dengan PERMENPAN-RB No.13 Tahun 2014.

Pelaksanaan lelang jabatan di lingkungan pemerintahan Kota Padang belum efektif yang dilihat dengan PERMENPAN-RB No.13 Tahun 2014, ada empat tes yang tidak dilakukan dalam pelaksanaan lelang jabatan di Kota Padang yaitu tes kompetensi bidang, wawancara akhir, rekam jejak dan tes kesehatan dan psikologi. Dalam PERMENPAN-RB No.13 Tahun 2014 ada 3 tahapan dalam pelaksanaan lelang jabatan, yaitu: (1) Persiapan: pembentukan Panitia seleksi yang belum terlaksana dengan maksimal karena tidak memperhatikan latarbelakang keilmuwan Panitia Seleksi; (2) Pelaksanaan terdiri atas beberapa tahap: pengumuman, seleksi administrsi, seleksi kompetensi, wawancara akhir, penelusuran (rekam jejak), hasil seleksi dan tes kesehatan dan psikologi, dari 7 hal tersebut ada 4 bagian yang tidak dilakukan secara optimal diantaranya tes kompetensi bidang tidak dilakukan sedangkan wawancara akhir, rekam jejak dan tes kesehatan dan psikologi tidak terlaksana dengan optimal sesuai dengan peraturan. Hal ini dikarenakan sedikitnya anggaran pelaksanaan lelang jabatan sehingga tidak memungkinkan untuk melakukan semua tes tersebut.(3) Monitoring dan evaluasi sudah dilakukan dengan baik yaitu pengawasan dilakukan oleh KASN yang dilakukan dalam bentuk laporan tertulis diawal dan akhir kegiatan. 
Solusi untuk meminimalisir kendala-kendala dalam pelaksanaan lelang jabatan di lingkungan pemerintahan Kota Padang dalam hal adanya peraturan baru beserta anggaran yang sedikit yaitu dengan optimalisasi penggunaan anggaran yang ada dalam pelaksanaan lelang jabatan dengan cara mengurangi Anggota Sekretariat Panitia Seleksi yang biasaya 12 orang menjadi 9 orang. Merubah metode seleksi sesuai dengan dengan kemampuan anggaran yaitu dengan melakukan perubahan pada metode CAT menjadi metode ujian tertulis biasa tanpa menggunakan komputer.

2. Saran

Berdasarkan hasil temuan maka dapat diketahui bahwa pelaksanaan lelang jabatan di Kota Padang belum terlaksana dengan efektif, maka peneliti memberikan saran sebagai berikut:

a. Penambahan anggaran untuk pelaksanaan lelang jabatan di Kota Padang.

b. Penyusunan anggaran sebaiknya memasukkan biaya tak terduga seperti adanya peraturan baru yang nantinya tidak akan menjadi kendala jika ada kebijakan baru yang keluar.

c. Pemilihan Panitia Seleksi sebaiknya dengan melihat latar belakang keilmuwannya. Seharusnya Panitia Seleksi adalah orang-orang yang memiliki latar belakang keilmuwan yang sesuai dengan jabatan yang akan dilelang sesuai dengan Peraturan yang ada.

d. Panitia Seleksi dari komponen eksternal sebaiknya adalah orang yang berasal dari luar Kota Padang, sehigga antara panitia seleksi dengan pelamar tidak saling mengenal, maka penilaian dapat dilakukan dengan lebih objektif.

\section{DAFTAR KEPUSTAKAAN}

Donni Juni Priansa \& Agus Garnida. 2013. Manajemen Perkantoran. Bandung: Alfabeta.

Melayu S.P Hasibuan. 2011. Manajemen: Dasar, Pengertian, dan Masalah. Jakarta: Bumi Aksara.

Melayu S.P Hasibuan. 2012. Manajemen Sumber Daya Manusia. rev.ed.Jakarta: Bumi Aksara.

Sondang P. Siagian. 2011. Manajemen Stratejik. Jakarta: Bumi Aksara.

Sondang P. Siagian. 2001. Sistem Informasi Manajemen. Jakarta: Bumi Aksara.

Suwatno \& Donni Juni Priansa. 2014. Manajemen SDM dalam Organisasi Publik dan Bisnis. Bandung: Alfabeta.

UU No. 5 Tahun 2014 tentang Aparatur Sipil Negara.

PERMENPAN-RB No. 13 Tahun 2014 tentang Tara Cara Pengisian Jabatan Pimpinan Tinggi Secara Terbuka Di Lingkungan Instansi Pemerintah. 
Made Gede Budhiarta. 2005. Pengembangan Model Pola Karir Pejabat Struktural melalui Job Tender di Sekretariat Daerah Kabupaten Jembrana. Tesis Program Pasca Sarjana. Universitas Airlangga Surabaya.

BKPSDM Kota Padang. www.bkd.padang.go.id, diakses 11 Januari 2018.

Kabar Nagari. 2016. Berikut Komentar Hangat Legislator Terkait Lelang Jabatan Sekda Kota Padang. www.kabarnagari.com, diakses 17 Januari 2018. 